Cite as:

Lopes, PFM \& Villasante, S. 2018. Paying the price to solve fisheries conflicts in Brazil's Marine Protected Areas. Marine Policy 93:1-8.

\title{
Paying the price to solve fisheries conflicts in Brazil's Marine Protected Areas
}

\author{
Priscila F. M. Lopes ${ }^{\mathrm{a}^{*}} \&$ Sebastián Villasante ${ }^{\mathrm{b}}$
}

${ }^{a}$ Fishing Ecology, Management and Economics (FEME), Department of Ecology, Federal University of Rio Grande do Norte, Natal, Brazil, priscila@cb.ufrn.br

${ }^{b}$ Faculty of Political and Social Sciences, University of Santiago de Compostela, A Coruña, Spain, sebastian.villasante@usc.es

*to whom the correspondence should be addressed

\begin{abstract}
Ecosystems services (ES) provide food and recreation to humans, but are fast being degraded. Marine Protected Areas (MPAs) have been proposed as a way to protect some of these ES, but decisions regarding what gets protection and what gets consumed can be a source of conflicts. One such example is the Fernando de Noronha MPA (Brazil), where there is a conflict between shark-directed tourism and fishers who would like to access the no-take part of the MPA during part of the year. A contingent valuation method (Willingness to Pay) was used to ascertain if tourists would accept compensating fishers for not disturbing the sharks during a specific period of the year, by adding a symbolic increase in the taxes they already pay to either visit the island or to visit the no-take part of the MPA. Tourists were open to this alternative (67-71\%), regardless of the fee being paid. However, there was a slight tendency to reject the fee when the tourists saw sharks during their stay, suggesting that a closer contact with these animals triggered a less sympathetic attitude towards fishers, probably because they start seeing fishers as wrongdoers, even if this is the worst choice for conservation. Although such a hypothetical payment was easily accepted by the majority of the tourists and could represent an affordable solution to conflicts, convincing those who reject such social compensation, especially if based on an irrational choice, would be an important step for sharks and for the MPA as a whole.
\end{abstract}

\section{Keywords:}

Willingness to Pay; Payment for Ecosystem Services; shark conservation; shark tourism; Fernando de Noronha. 


\section{Introduction}

All over the world, tropical areas are increasingly being used for their ecosystem services (ESs) [1], sometimes to the point of exhaustion or at least for conflicting and unsustainable uses [2]. One way to protect ESs is through the establishment of protected areas [3]. There are multiple categories of protected areas, some are very restrictive, where only research is allowed, and others are lax enough to allow the sustainable exploitation of their resources [4]. Such variation in the degree of protection can be found in terrestrial and marine environments.

The establishment of Marine Protected Areas (MPAs) is still occurring at a relatively slow pace in relation to its terrestrial counterpart. At the Seventh Conference of the Parties (COP 7) in 2004, governments agreed to protect $10 \%$ of the marine habitats by 2012 [5]. In October 2013, IUCN estimated the actual rate only approached three percent and that it was likely the world would reach the initial goal only after postponing the deadline to $2020^{1}$. Assuring a certain degree of protection is essential to the continuing provisioning of the marine ESs that people depend upon [6].

MPAs protect ecosystems that provide direct and indirect ESs [7], depending on the degree and effectiveness of protection of these areas. Among the human activities that make use of ecosystem services, two are particularly important and related in the tropics: ecotourism [8] and fisheries [9]. Tropical MPAs, when in a good conservation state, can be a more reliable provider of fish than unprotected neighboring areas, working as a source to the latter through the spillover effect [10]. Resident, migratory and even species with sensitive life history aspects (e.g., long lifespan, late maturity, few offspring), such as sharks, can benefit from such areas [11]. Abundant fish attracts the attention of fishers and recreational divers alike.

Shark diving tourism is a profitable business, annually generating over USD 314 million, an evergrowing figure [12]. Tropical fisheries, on the other hand, are in some places the only source of food and cash for vulnerable poor communities [13]. Both activities have in common that they rely on having access to plenty of fish in the long-term, even if the species are not the same. Shark diving tourism is taken as a non-consumptive ES, where its occurrence is less likely to affect the abundance and diversity of fish. Fishing, on the other hand, consumes the resources it depends upon, and even if not focused on sharks, could disrupt the trophic chain, depending on

\footnotetext{
${ }^{1}$ http://www.iucn.org/content/world-nearing-3-ocean-protection
} 
how it is done and on how much fish biomass is removed from an area [14]. Additionally, there is always the chance of incidental catch, when non-target species are caught, sometimes at considerable numbers [15]. Therefore, the sustainable maintenance of livelihoods through fisheries and of shark diving tourism demands the establishment of a middle ground in the use of ecosystems. The lack of an agreement between different uses can lead to conflicts, which ultimately can threaten the already insufficient conservation endeavors [16].

The establishment of protected areas may alter land-use rights, by exclusion, restriction or even by passing these rights to others [17], such as to a local or an external elite [18]. It can also result in the criminalization of natives for their original practices [19]. Conflicts between users and MPAs can jeopardize their effectiveness to the point of making some MPAs less successful than the unprotected areas that surround them [20]. This would be the case when fishers or other users specifically target the MPA to make a political point, for disagreeing with their presence or with the way they were arbitrarily established.

In Brazil, the first protected areas followed the American style of native dispossession to protect an area from any human use, other than contemplation [21]. However, from the late 1980s on, natives and locals saw an opportunity to ally nature protection to land-rights by creating new categories of protection that allowed human presence $[22,23]$. Whereas some of these areas have been successful, others face difficulties either because of market pressure on their natural resources that encourage people to break the rules or because of difficulties stemming from arrangements made in the past that cannot be supported by current legislation.

In this study, an economic tool was used to propose alternatives to social conflicts regarding the use of ecosystem services by small-scale fisheries and shark diving tourism. The case study was in the MPA of Fernando de Noronha (Brazil), the main shark diving tourism destination on the south Atlantic coast, which also hosts a traditional community of small-scale fishers. According to some stakeholders (some managers at the time of the study, for instance), fisheries threaten shark diving tourism by interfering with the trophic chain or with shark behavior; whereas fishers feel they have lost their traditional rights, and are forced to give way to tourism interests. Although this MPA was first designed to accommodate local fishers' interests, legislation changes, tourism growth, and mismanagement created a conflict that could threat the current MPA status [20]. Therefore here it was assessed if tourists were willing to compensate fishers for their economic losses due to restrictive access to fishing grounds in order to not disturb sharks. 
The findings of this study look into alternative economic ways to solve or ameliorate conflicts that arise when certain ES are used by one activity and restricted to others due to a protected area. Solving conflicts is an important step to assure the effectiveness of protected areas [24], through improved compliance [25].

\section{Material and Methods}

\subsection{Fernando de Noronha, conflicts from an MPA}

Fernando de Noronha is a $26 \mathrm{~km}^{2}$ MPA, located $345 \mathrm{~km}$ off the South Atlantic coast of Brazil ( $3^{\circ}$ $51^{\prime} 13.71^{\prime \prime} \mathrm{S}, 32^{\circ} 25^{\prime} 25.63^{\prime \prime} \mathrm{W}$ ), which is zoned into two management categories: a no-take zone that encompasses $70 \%$ of the MPA, where visitation is limited and only allowed under a fee, and a sustainable use zone, where fishing, diving and tourism are allowed (Figure 1). In 2014 and 2015 , the number of people who entered the no-take zone was 63,896 and 76,472 , respectively. These figures, together with the monthly number of divers, were provided by ICMBio, the federal agency that manages all federal protected areas in Brazil.

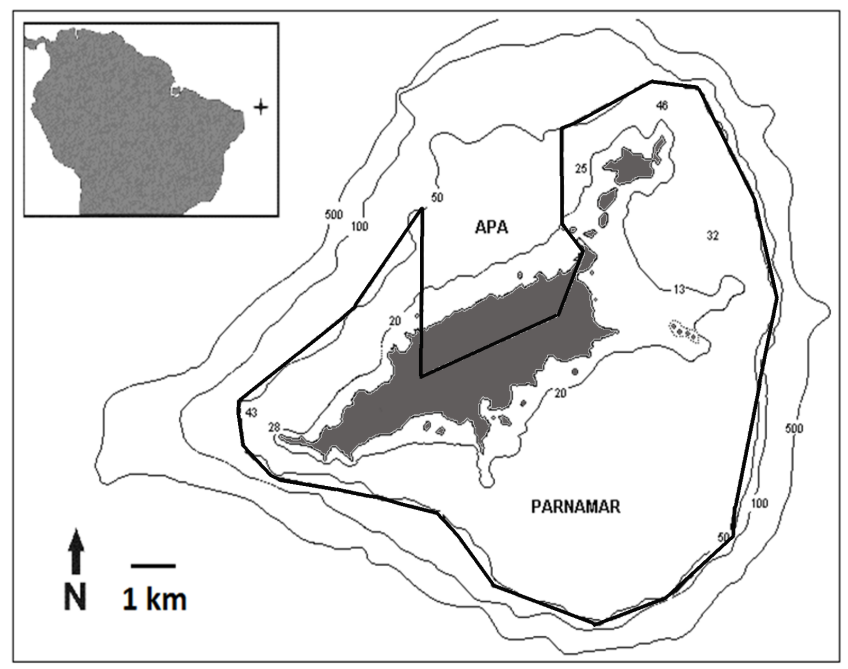

Figure 1. The Marine Protected Area of Fernando de Noronha, an oceanic archipelago off the northern coastline of Brazil. The MPA is divided into two areas, according to the Brazilian conservation code: an Environmental Protected Area (from Portuguese Área de Proteção Ambiental - APA) where some uses are allowed and residency is permitted, and a no-take area (Parque Nacional Marinho - PARNAMAR) where consumptive use is not allowed (e.g.: fisheries) and visitation is controlled. The numbered lines represent different depth contours. The thick black line represent the limits of the no-take zone, whereas the sustainable use zone includes part of the land and the area not limited by the black line. Note that the notake zone follows the $50 \mathrm{~m}$ deep contour line. 
The MPA comprises an archipelago that includes a large inhabited island plus other 19 small islands. The GDP of the island, estimated at about BRL 78 million in 2015 (USD PPP 42.18 millions) [26] or BRL 15,600 per capita (lower than the Brazilian GDP per capita, BRL 28,876), comes mainly from tourism (general nature and diving tourism) [27]. Diving, specifically, attracts about 24,000 people annually, due to its warm, clear and fish-rich waters [27]. The beaches of the archipelago are a nursery and breeding ground for resident sharks. Among the most common sharks in the area, there are the Caribbean (Carcharhinus perezi), nurse (Ginglymostom acirratum) and lemon (Negaprion brevirostris) sharks. The archipelago waters are also regularly visited by tiger (Galeocerdo cuvier) and silk (Carcharhinus falciformis) sharks. Sharks are easily sighted, even from the beaches. This has turned Fernando de Noronha into the main sharkdestination of the Atlantic coast of South America [27], especially sought by divers. Wildlife education and conservation are not specifically addressed by dive companies, but the park holds free daily talks on different conservation issues. These talks are the main evening event in the island, with the one concerning sharks being the most popular.

Predating the tourist boom, however, Fernando de Noronha was first and foremost a fishing island. Fishing sustained the local livelihood, culture and food security. Later, shark fishing became important, especially between 1992 and 1997, when a shark-directed fishery operated on the island, targeting multiple species, including C. perezi [28]. Tour operators believe that this particular species has been severely depleted during the shark fishing period [28]. Currently sharks are not intentionally fished by local fishers, although non-endangered species are still regularly caught outside the MPA limits by fishers coming from the mainland. Local fishers target mainly tuna and other large pelagic species caught outside the park limits, as these are the species demanded by local restaurants [20]. Handline fishing is the main method used and is highly dependent on fresh sardines as bait, caught early morning on the coast. For most of the year, fishers can catch the sardines within the sustainable use zone with castnets on the surf zone. However, for about four months out of the year, the sea is rough in this area, whereas the no-take zone becomes calm. This is when there is a conflict between park managers and fishers, as the latter feel it is their inherited right to fish wherever they need. The period in which the permitted area is unfishable was not factored in the original MPA design established in 1988, because both fishers and managers at the time understood that local fishers would keep fishing in this area when necessary. However, new federal legislation established in 2000 banned any extraction in 
some categories of protected area, including "parks", and some subsequent managers chose to follow the rule to the letter.

Based on interviews, it was estimated here that fishers remove between $60-80 \mathrm{~kg}$ of sardines daily from the coast of Fernando de Noronha. For that estimate, fishers were specifically asked how much sardine, on average, they catch before going fishing at sea. Estimates ranged from $3 \mathrm{~kg}$ to $12 \mathrm{~kg}$, with most around $6 \mathrm{~kg}$. The average was multiplied by the number of boats fishing at the time of the study. According to the fishers, this is not a significant amount, even if it is done within the no-take zone, an opinion not shared by some of the park managers. In conversations with the latter in 2014, they posited that besides being a no-take zone that should be enforced as such, the use of castnets would disturb lemon sharks that also come to the shore to feed on sardines, and juvenile or mating nurse sharks that use the surf zone. Some managers also claimed, during interviews, that affecting such sharks would have an effect on shark diving tourism happening offshore, as the sharks would be scared away from the archipelago. However, no study has ever been done to support either the fishers or the managers' claims.

The island today hosts 40 active fishers who depend on the pelagic fishery; 35 of those were interviewed. Fishers were asked to estimate their losses due to the interdiction on catching sardines within the park limits, which would impede part of their pelagic fishing due to lack of fresh sardines as bait; with this figure, it is possible to estimate their regular income. According to the fishers, without fresh sardines, their catch drops by half (median of the answers $=50 \%$; average $=59 \%$ ), meaning a loss of about BRL 2.000/month over the course of that four-month period. Clearly, such losses can vary from year to year, but for the sake of simplicity, it is used as a fixed value. This would imply a general compensation of BRL 256.000 annually for the 40 fishers, which represents about one week per month of what the island gets for charging tourists a daily fee (BRL 56.80 in May 2016) to stay on the island. In other words, it would represent a small increase of BRL 1.20 in the daily fee (about USD PPP 0.60 in 2016). As of May 2016, tourists also paid a second fee to enter the no-take zone (BRL 89 for Brazilians and BRL 178 for foreigners, for a multiple-entry ticket valid for 10 days). Since this is an issue of concern between the park authorities and the fishers, some tourists could argue that the park should be the entity that manages this compensation. If that were the case, it would be necessary to increase the park entrance for both Brazilians and foreigners alike. However, since foreigners are a minority, for simplicity's sake here only the increase needed from the Brazilians, in order to compensate 
fishers, was estimated; this raise was established at BRL 3.50, following the same steps described for the island fee.

The park fee is administered by a private company that maintains the infrastructure of the park, and part of it is transferred to the ICMBio administration for their own maintenance. The island's fee is supposed to maintain the island infrastructure and is directly linked to its political administration.

\subsection{Contingent valuation method to estimate Willingness-to-Pay (WTP)}

It was tested if tourists were hypothetically willing to pay to keep fishers away from beaches that are now entirely protected. For that, a contingent valuation estimate of willingness to pay (WTP) was used [29]. The WtP approach is not meant to bring all the complexity of the system together. For example, the presence of sharks in the archipelago does not depend solely on fisheries, although some species can be highly affected by fishing extraction [30]. Nevertheless, the WtP findings can act as guidelines to support the functioning of MPAs [31].

Tourists were approached at random on the beaches and at the airport ( $N=579$ interviews). The interviewers identified themselves as academics interested in investigating hypothetical solutions to one of the island's conflicts. Only tourists that were over 18 years old and willing to respond to the survey were approached; only one person per family was interviewed and always individually. If a tourist was approached at the beach, he or she was interviewed regarding their willingness to compensate fishers through an increase in the park access fee. If he or she was approached at the airport, the interview regarded an increase in the island fee (Table 1). The first step, after explaining the goal of the research, was to give the person a card with some background information on the relevance of sharks and of small-scale fisheries, besides some information about the ongoing conflict. The interviewers were cautious to present the information in an unbiased form, for instance, by making sure to inform the respondent that fishers did not target sharks. The order of the information given about sharks or SSF was alternated to avoid and test for sequencing effect [32]. After a tourist finished reading both cards, he or she was told that one hypothetical option to end the conflict would be to compensate fishers for their economic losses over the course of four months, and the money for that could come from an increase either in the no-take park fee or in the island fee (depending on where the interview took place), which were the payment vehicles used herein. In this hypothetical scenario, the proposed money would 
be given to the park, which would administer the individual payments. It was made clear who would be managing the money, because otherwise people might assume that the federal government would do it, which could have resulted in protest answers [33]; this is due to the public's general viewpoint that the Brazilian government is associated with corruption and bureaucracy.

After giving this information, interviewees were asked if they would pay a fixed amount from one of two options to compensate fishers for not fishing, thereby abstaining from interference with sharks (Table 1). The question was framed as:

Today the (park access fee or the island fee) is $\$ X$ to (access the park for 10 days or per day). Would you pay $\$ X+Y$ if the extra $\$(Y)$ were used to compensate fishers for the period they would not fish?

The information between parentheses was chosen according to the interview being done, either regarding an increase in the park fee or in the island fee. $\mathrm{X}$ here represents the value tourists were paying for either of the fees at the moment of the interview, and $\mathrm{Y}$ is the extra hypothetical amount to be added to the fee, as described in Table 1.

The word choice of the question aimed to balance both the conservation and the social sides of the conflict in order to avoid influencing the tourists' answers. For instance, if the question stated that the extra money would be used to protect sharks from fishers, fishers would be placed into a negative context.

This method, where one of $N$ fixed values is offered, is known as the simple referendum method. The lowest value offered represented the amount necessary to compensate fishers for four months without catching sardines, while the second value would be enough to cover half of the year without fishing. The price options were randomly assigned to interviewees in order to have a relatively balanced sample. Here there was no interest in testing the price effect on the interviewee's answer, the intention was to provide reasonable alternatives that can eventually be used by the park itself to solve an existing conflict. This explains why small differences in price options were used.

The tourists were also interviewed about some basic socio-economic and perception variables that could help explain their WTP choice, specifically:

- income (continuous),

- education level (categorical), 
- age (continuous),

- gender (categorical),

- if they eat fish/seafood (binary),

- the number of days they stayed or planned to stay on the island (continuous),

- if they saw sharks while at the island (binary), and

- how important seeing sharks was for their decision to come to the island (categorical variable on a scale from 1 to 5, where 5 represented highly important; Likert Scale).

The questionnaires were pre-tested with 282 people, and then readjusted to exclude foreigners (there were not enough foreigners visiting the island in 2016); to make sure people properly understood the intention of the research and to avoid referring to what was a contentious political moment in Brazil, and which otherwise might have resulted in answers that would reflect the internal political division. For instance, in the pre-test over $20 \%$ of the interviewees stated they would not pay anything because they were against any sort of government social support to the poor (fishers in this case), a response rarely seen in the subsequent interview periods.

Table 1. Real prices (BRL) paid by tourists and options offered to compensate fishers for their economic losses when they cannot catch sardine outside the no-take zone (conversion rate in 2016: USD PPP $1=$ BRL 1.995). A tourist would be presented either Option 1 or 2 . The number inside parentheses corresponds to the number of interviews done for each option.

\begin{tabular}{ccc}
\hline Value of the fee & Island fee $(\mathbf{N})$ & Park fee $(\mathbf{N})$ \\
\hline At the moment of the interview & 56.80 & 89.00 \\
Option 1 & $57.80(111)$ & $92.50(177)$ \\
Option 2 & $58.80(131)$ & $94.50(160)$ \\
\hline
\end{tabular}

Chi-square tests were used to test differences in the proportions of answers, such as a higher or lower rejection rate for the payment of different options. A Mann-Whitey test was run to compare the Likert Scale on how important it was for the interviewee to see sharks.

The WTP data was analyzed using binomial logistic (logit) general linear models (because the answers were either yes or no regarding the payment), using the socio-economic and background information as explanatory variables, according to the following model:

$$
\lambda=\alpha+X_{i j} \beta
$$

(equation 1) 
where $\alpha$ is the intercept, $\beta$ represents the vector of the regression coefficients, and $X_{i j}$ is the vector of explanatory covariate.

The bid value was not included in the model because the interviewees were not sensitive to price variation (chi-square test), given the slight difference between the bid options. An ANOVA was run to test the improvement of the model after the sequential addition of each variable. For both models, the ANOVA confirmed the significance of the variables presented in the logit model as relevant (i.e., those with $\mathrm{p}<0.05$ ). The probability of the dependent variable $\lambda$ taking on the value 1 for given values of $X_{i j}$ was estimated as follows:

$\rho(\lambda)=\frac{e^{\alpha+X_{i j \beta}}}{1+e^{\alpha+X_{i j \beta}}}$ (equation 2)

All tests were run using the software R, with the regressions done with the package glm2 [34].

\section{Results}

The average number of entrance tickets to the no-take area sold to Brazilian and foreign tourists in 2014 and 2015 reached slightly over 70,000 people per year, with a monthly peak in October of over 6,700 . Brazilians made up more than $80 \%$ of the tourists, meaning that the total revenue generated by tourists visiting the park only from entrance tickets was about BRL 7.5 million year $^{1}$ (for other sources of revenue generated by ecotourism, such as accommodation, please check [27]). Scuba diving revenue shows the same peak in October, when it reaches an average of BRL 1.5 million. In 2014 and 2015, on average the three diving operators generated

almost BRL 13.5 million year $^{-1}$, with most dives happening within the boundaries of the no-take area of the MPA and its coasts. The total revenue generated by recreational activities is thus the sum of entrance tickets to the no-take area plus the scuba diving trips, which reached BRL 21 million a year ${ }^{1}$.

A total of 337 people were interviewed at the beach and 242 people at the airport regarding their willingness to accept an increase in the park entrance fee or island fee, respectively (Total $\mathrm{N}=$ 579). The order of the information presented to tourists about sharks or SSF did not influence their answer (Anova F-value Park fee $=0.134 \mathrm{p}>0.715 ; \mathrm{F}$-value Island fee $=0.008 \mathrm{p}>0.928$ ). The tourist profile was very similar, regardless of the interview answered (Table 2). However, it is 
noteworthy that tourists who answered the interview when they were leaving the island attributed more importance to seeing sharks than those who were still enjoying their stay (Mann-Whitney U = 35960; two-tailed p-value $=0.007$ ). This could have been because the first group also had a higher percentage of people who actually had seen sharks during their time there $(72.3 \% \mathrm{x}$ $63.8 \%$ ), which may have made them reconsider their first opinion or made them believe that they always attributed more importance to sharks.

Table 2: Survey respondents' characteristics. The Park Fee interview was administered to tourists on beaches, whereas the Island Fee interview was administered to tourists at the airport, when leaving the island (conversion rate in 2016: USD PPP $1=$ BRL 1.995).

\begin{tabular}{c|c|c}
\hline Characteristic & WTP - Park fee $\mathbf{~} \mathbf{N}=\mathbf{3 3 7})$ & WTP - Island fee $\mathbf{N}=\mathbf{2 4 1})$ \\
\hline Monthly income & $\mathrm{R} \$ 15.718,45( \pm \mathrm{R} \$ 14.776,85)$ & $\mathrm{R} \$ 13.618,72( \pm 10.392,61)$ \\
Education & $91.4 \%$ higher education & $91.7 \%$ higher education \\
Age & $40.1( \pm 13.9)$ & $39.2( \pm 12.2)$ \\
Gender & $63.7 \%$ female & $56.2 \%$ female \\
Eat fish/seafood & $93.8 \%$ eat fish/seafood & $96.3 \%$ eat fish $/$ seafood \\
\#days at the island & $6.1( \pm 2.6)$ & $5.5(2.0)$ \\
Saw sharks & $63.8 \%$ saw sharks & $72.3 \%$ saw sharks \\
How important was seeing a & 1 (not important) $=47.8 \%$ & 1 (not important $)=38.0 \%$ \\
shark (from 1 to 5) & $2-4$ (mildly important) $=$ & $2-4$ (mildly important) $=$ \\
& $38.0 \%$ & $34.7 \%$ \\
& 5 (very important) $=14.2 \%$ & 5 (very important) $=27.3 \%$ \\
\hline
\end{tabular}

The overall rejection rate regarding paying an extra value to compensate fishers was $29.7 \%$, with tourists being slightly less inclined to pay the island fee (33\%) than the park access fee $(27.3 \%)$. The reasons for rejecting any increase were very similar in both cases: most people believed that the prices are already too high and, if needed, the money to compensate fishers should come from the original fee. Others, despite the efforts to detach the research from the general public's distrust for Brazilian governmental institutions, stated that they would not trust that this money would actually ever be given to fishers. In both cases, the rejection tended to be higher for the highest payment option, although this figure was not statistically significant (chi-square, $\mathrm{p}>0.1$ ) (Table 3) 
Table 3: Simple referendum results for the Willingness to Pay for an extra amount on the daily island fee or on the total park fee (conversion rate in 2016: USD PPP $1=$ BRL 1.995).

\begin{tabular}{ccc}
\hline Additional amount & "Yes" - Park fee & "Yes" - Island fee \\
\hline $\mathrm{R} \$ 1.00$ (island)/ $\mathrm{R} \$ 3.50$ (park) & $70.3 \%$ & $76.3 \%$ \\
$\mathrm{R} \$ 2.00$ (island)/ $\mathrm{R} \$ 5.50$ (park) & $64.1 \%$ & $68.8 \%$ \\
\hline
\end{tabular}

The binary logistic regression analyses identified those tourists who would be more willing to pay to compensate fishers for a period without fishing, i.e. which would keep the park as a notake area. The results were slightly different for each model (Table 4), but both sets of models are alike in that a tourist who actually saw a shark during the stay on the island is less likely to approve of compensating fishers for their non-active period.

For the park fee vehicle, the final model included the age of the interviewee and noted whether or not he or she had seen a shark as significant factors. Both factors affected the WTP negatively, although the effects were small and non-linear. For instance, people who saw sharks were 0.55 times less likely to accept paying a compensation for fishers, whereas for every unit of age added, i.e., year, the interviewee got 0.98 less likely to pay (Table 4). However, the effect of age is nonlinear and slightly biased towards a small sample of people older than 75. As an example, the odds of somebody who saw a shark, who was 65 years old and who approved of compensating fishers was $54.9 \%$, whereas a 20 year-old person, who also saw a shark, would have odds of $78.3 \%$.

For the island fee vehicle, the final model included having seen a shark and the number of days the interviewee planned to stay on the island as significant variables. Again, the effects of these variables were negative on tourist WTP. Specifically, every additional day a person stayed on the island reduced the chances of accepting the payment by 0.85 times, whereas having seen a shark during the stay reduced the chance of paying by 0.50 times (Table 4). As an example, the odds of somebody who stayed on the island for five days and who saw a shark and was willing to compensate fishers was $65.1 \%$. If this person had stayed for only one day, the chances would have been $77.7 \%$. 
Table 4. Logit model results for respondent decision to pay.

* Significant at the 5\% level. Odds ratio are presented for the significant variables.

\begin{tabular}{|c|c|c|c|c|c|c|}
\hline \multirow[b]{2}{*}{ Variable } & \multicolumn{3}{|c|}{ Island fee model } & \multicolumn{3}{|c|}{ Park fee model } \\
\hline & $\begin{array}{l}\text { Parameter } \\
\text { estimate }\end{array}$ & $\begin{array}{c}\text { Standard } \\
\text { error }\end{array}$ & $\begin{array}{l}\text { Odds } \\
\text { ratio }\end{array}$ & $\begin{array}{l}\text { Parameter } \\
\text { estimate }\end{array}$ & $\begin{array}{l}\text { Standard } \\
\text { error }\end{array}$ & Odds ratio \\
\hline Intercept & $1.574 \mathrm{e}+01$ & $7.226 \mathrm{e}+02$ & NA & $3.191 \mathrm{e}+01$ & $1.590 \mathrm{e}+03$ & NA \\
\hline Income & $2.986 \mathrm{e}-06$ & $1.427 \mathrm{e}-05$ & NA & $4.449 \mathrm{e}-06$ & $9.976 \mathrm{e}-06$ & NA \\
\hline $\begin{array}{l}\text { School Complete } \\
\text { High School }\end{array}$ & $-1.528 \mathrm{e}+01$ & $7.226 \mathrm{e}+02$ & NA & $-1.506 \mathrm{e}+01$ & $6.391 \mathrm{e}+02$ & NA \\
\hline $\begin{array}{l}\text { School } \\
\text { Incomplete High } \\
\text { School }\end{array}$ & $-1.585 \mathrm{e}+01$ & $7.226 \mathrm{e}+02$ & NA & $-1.595 \mathrm{e}+01$ & $6.391 \mathrm{e}+02$ & NA \\
\hline $\begin{array}{l}\text { School Grad } \\
\text { School }\end{array}$ & $-1.407 \mathrm{e}+01$ & $7.226 \mathrm{e}+02$ & NA & $-1.487 \mathrm{e}+01$ & $6.391 \mathrm{e}+02$ & NA \\
\hline $\begin{array}{l}\text { School Complete } \\
\text { College }\end{array}$ & $-1.469 \mathrm{e}+01$ & $7.226 \mathrm{e}+02$ & NA & $-1.477 \mathrm{e}+01$ & $6.391 \mathrm{e}+02$ & NA \\
\hline $\begin{array}{l}\text { School } \\
\text { Incomplete } \\
\text { College }\end{array}$ & $-1.433 \mathrm{e}+01$ & $7.226 \mathrm{e}+02$ & NA & $-1.399 \mathrm{e}+01$ & $6.391 \mathrm{e}+02$ & NA \\
\hline Age & $1.139 \mathrm{e}-02$ & $1.279 \mathrm{e}-02$ & NA & $-2.496 \mathrm{e}-02 *$ & $9.419 \mathrm{e}-03$ & $\begin{array}{c}9.75 \mathrm{e}-01(9.6- \\
9.9 \mathrm{e}-01)\end{array}$ \\
\hline Gender M & $2.526 \mathrm{e}-01$ & $3.054 \mathrm{e}-01$ & NA & $-1.468 \mathrm{e}+01$ & $1.455 \mathrm{e}+03$ & NA \\
\hline Eat fish & $3.212 \mathrm{e}-01$ & $7.320 \mathrm{e}-01$ & NA & $-4.657 e-03$ & $5.173 \mathrm{e}-01$ & NA \\
\hline Has seen shark & $-6.621 e-01 *$ & $3.461 \mathrm{e}-01$ & $\begin{array}{c}5.16 \mathrm{e}-01 \\
(2.6-9.9 \mathrm{e}- \\
01)\end{array}$ & $-5.453 \mathrm{e}-01 *$ & $2.881 \mathrm{e}-01$ & $\begin{array}{c}5.79 \mathrm{e}-01(3.3- \\
1.02 \mathrm{e}+00)\end{array}$ \\
\hline $\begin{array}{l}\text { Importance of } \\
\text { seeing a shark }\end{array}$ & $-2.732 \mathrm{e}-02$ & $8.896 \mathrm{e}-02$ & NA & $5.759 \mathrm{e}-04$ & $8.753 \mathrm{e}-02$ & NA \\
\hline Days MPA & $-1.545 e-01 *$ & $7.320 \mathrm{e}-02$ & $\begin{array}{c}9.73 \mathrm{e}-01 \\
(8.2-1.6 \mathrm{e}- \\
01)\end{array}$ & $-3.609 e-02$ & $4.803 \mathrm{e}-02$ & NA \\
\hline
\end{tabular}

\section{Discussion}

Despite high expectations placed on MPAs, in many instances they have not been able to stop deterioration of marine environments, sometimes due to exclusion of important, but overlooked stakeholders, who are mostly artisanal fishers [24]. By carefully considering the aspirations and expectations of fishers part of the secret to long-term success of MPAs may be unlocked [35], especially in those where conflicts between users and managers lead to non-compliance behavior [25]. Here a conflict between shark directed tourism and fisheries was investigated by assessing 
the potential of using an economic tool to solve or ameliorate such conflict. Specifically, the possibility of maintaining tourism and fisheries revenues by compensating fishers for their time away from fishing was explored. This option showed promising results, as the compensation could be easily achieved with a symbolic increase in taxes already paid by tourists. The choice was for using realistic price options that could solve an existing problem instead of testing the effect of implementing different prices. By doing that, the chances that respondents would be overestimating their real desire to pay an extra fee when facing a real situation was also probably decreased [36].

Overall, most tourists (67-71\%) would accept paying more to visit the archipelago or to enter the no-take zone if this extra money were given to fishers. Such an alternative would be a win-win solution, as it would encompass maintaining the current economic gains of tourism, an increase in fisher income and the maintenance of the shark status. Although this is a simplified approach, because it posits that the presence of sharks in the archipelago is solely dependent on fisheries, some studies suggest that reef sharks specifically can show high site fidelity once protected from fisheries, regardless of other environmental factors [30].

Offering compensation to fishers for their income indirectly lost due to tourism could be an alternative to decreasing or mitigating ongoing conflicts, especially because the economic benefits of tourism do not spillover directly to fishers [37]. Such compensation could be interpreted as a payment for environmental services (PES), as fishers would be receiving it for maintaining fisheries, including sharks. Brazil already has a specific PES system that compensates fishers during closed seasons to support the reproductive period of some species [38]. This system, as it exists now, varies from state to state and is only applicable to a few economically relevant species (e.g.: lobsters, shrimps, snook, etc.) during their reproductive season, which can vary from three to six months.

The approach suggested here is somewhat similar, as fishers would also be compensated for not fishing inside the no-take area, which is their demand and main point of contention. To alleviate tension, fishers would receive what they themselves estimate as their losses for not fishing in the no-take area for those four months of the year. From a financial point of view, this alternative is not far-fetched, as most tourists said they would be willing to cooperate with fishers. In fact, contrary to previous studies that used similar WtP choice models $[39,40]$, tourists here were not sensitive to the price being offered, probably because they thought the suggested increases were 
intentionally arbitrary, but enough to cover the additional expenses brought about by a PES. Additionally, the prices offered were likely seen as negligible when compared to the general prices levied in the archipelago [41].

From a pragmatic point of view, using this money to compensate fishers would require new legislation, as the existent PES compensates fishers specifically for not fishing during the reproductive period of target species, which is known as the closed period wage (or defeso in Portuguese). If such a barrier can be overcome, this compensatory mechanism is more likely to succeed than the original closed period wage does, which is usually unenforced [42]. Enforcement would be possible due to the isolation of the archipelago, with its well-established boundaries, small size, and constant monitoring and enforcement, which are key conditions for the successful management of social-ecological systems [43].

On the other hand, compensating fishers does not really address root problems concerning access rights. For example, in this case study, fishers may simply reject financial compensation if they insist on having their original access and withdrawal rights granted [44]. Through informal conversations it was apparent that younger ones would be prone to accept financial compensation, but older fishers, especially those that participated in the MPA creation process, would be resistant to this idea. Thus, valid as it may be, the implementation of a compensation program should be accompanied by additional measures and negotiations with fishers, such as the inclusion of transitional and adaptation periods. It would also require careful analysis of the local value chain and of the inflated fish demand caused by unplanned tourism [20].

As for the respondents, although most were open to paying an extra fee to compensate fishers for their losses, it is also worth discussing the peculiarities that make a person reply positively or negatively to this type of compensation scheme, because from understanding the subject's characteristics, appropriate compensatory mechanisms can be devised, with programs for specific target groups [40]. The most striking characteristic is the fact that those who actually saw sharks while on the island tended to be slightly less sympathetic to the fisher cause. In addition, people were more inclined to rate the importance of seeing sharks higher when they were leaving the island than when they were at the beginning or middle of their trip. It is possible that some tourists might have misunderstood the WTP experiment but, based on informal conversations with some of them afterwards, another speculation is also possible. Although slightly counterintuitive, this finding may be suggesting that closer contact with nature, and more 
specifically with sharks, develops in people a more benevolent attitude towards conservation, and less for its consumptive uses. However, people may have trouble establishing a direct connection between conservation and paying someone or a company not to use a resource. If that is the case, tourists, after spending more time on the island and interacting more with wildlife and sharks, may begin to see fishers more negatively and cannot bear the idea of compensating them, even if this implies shark protection for at least part of the year. Some studies have investigated what people actually think when answering WTP questions and found that their reasoning can sometimes be completely unrelated to the value being elicited and may even be arbitrary $[45,46]$. However, it is also worth investigating how people react when the mechanism being elicited aims to compensate who they already interpret or start interpreting as wrongdoers. This would be the case, for instance, if some compensation was being offered to a polluting company to stop its activities for part of the year, which many might think as unworthy of any compensation. Still, it would be crucial to identify whether closer contact with nature causes people to view traditional resource users as wrongdoers, as this could reinforce dangerous stereotypes about natives worldwide [47].

It is also interesting that people were slightly more likely to accept an increase in the island fee, which is paid daily, than an increase in the park entrance fee, which is paid only once. Considering that the respondents stayed in the archipelago for an average of 5.5 days, they would be actually paying more if their preferred choice were implemented (Park fee $=\mathrm{R} \$ 3.50$ to $\mathrm{R} \$ 5.50$, depending on the choice; Island fee $=\mathrm{R} \$ 5.50$ to $\mathrm{R} \$ 11.00$, depending on the choice and considering the average stay of 5.5 days). One possible interpretation of this fact is that people are affected by the initial price presented to them and do not think further on the calculations (especially in the case of the island fee), i.e. how much that choice would personally cost to each one, depending on how long they stay. All the interviewees were aware of the functioning of the fees, as they pay for the island fee in advance and are informed about the park fee upon their arrival. Those points were also reinforced during the interview, but in-depth WTP studies have surprisingly shown that a significant percentage of respondents do not make any economic reasoning when answering such questions [48].

Finally, although the majority of the interviewees accepted the idea of compensating fishers, those few that said that they would not do it, justified their decision based less on conservation issues than on an ideological reason. They mentioned, for instance, their distrust in the 
institutions and stated opinions such as support for the poor is the government's responsibility. Although the current survey was not designed to capture ideological views and only a few people clearly manifested them, other studies have shown that they can play an important role, depending on the issue approached (e.g., climate change and use of fossil fuels) [49,50]. Indeed, as observed during the pilot test, even specific heated political moments can affect people's responses and the validity of contingent valuation method, such as WtP; this phenomenon can also jeopardize the effectiveness of conservation initiatives. Therefore, caution is recommended not only in the designing of the survey [51], but also in the choice of the moment to administer it, in order to avoid peaks of polarization in society that may reflect the passions of the moment, rather than deep-seated beliefs or attitudes.

\section{Conclusions}

The suggested conflict between shark diving tourism and small-scale fisheries studied here requires the investigation of alternative scenarios that could lead to a healthy continuity of both activities. Having tourists compensate fishers for not interfering with the more vulnerable shark habitats (mating and nursing grounds) is an alternative that faces little opposition and recommends a small rise in fees already paid by the visitors. The next step for managers to adopt would be to actually implement such use of an increased fee, be it by direct transference to fishers or through mechanisms that allow a transition from sardine-dependent fishing to different methods. Devising alternatives to minimize conflicts in the use of ES in protected areas is an urgent need by many tropical countries [24], where it is usually the most economically vulnerable people who depend on the direct extraction of natural resources, resulting in a clash of interests between the poor and conservationists [52]. It is also important to consider the local context in order to adopt supporting measures to accompany financial compensations because some issues, such as access rights, may be equal or more relevant to shaping users' opinions and perceptions regarding an MPA. As a recommendation, future MPAs should outline clear compensatory mechanisms to support the transition from a resource-consumptive economy to non- or less consumptive alternatives for those directly affected by conservation, who might find it difficult to deal with short- or long-term loss of access to a country's natural resources [53]. 


\section{Acknowledgements}

We would like to thank all participating tourists for sharing their time with us. We are also very thankful to the managers of the airport of Fernando de Noronha and to the managers of Fernando de Noronha MPA, who kindly provided the data on the number of tourists and scuba divers. Special thanks to Felipe Cruz, Thayná Melo and Júlio Rosa from ICMBio and to Ali Ger, Ludmila Damásio and Liana Mendes for their help in the fieldwork. We thank the advisory and economic support provided by LACEEP (Latin American and Caribbean Environmental Economics Program). Special thanks to Nancy Olewiler for her critical, positive and always accurate comments and to two anonymous reviewers. PFML also thanks CNPq for a productivity grant.

\section{Role of the funding source}

This work was supported by LACEEP (Latin American and Caribbean Environmental Economics Program) (Grant 192/2015), whose advisors also provided comments on the design, development and writing of the manuscript.

CNPq played no role in the study.

\section{References}

[1] K.S. Bawa, W.J. Kress, N.M. Nadkarni, S. Lele, Beyond paradise: meeting the challenges in Tropical Biology in the 21st century, Biotropica. 36 (2004) 437-446. doi:10.1111/j.17447429.2004.tb00341.x.

[2] M. Rao, P.J.K. McGowan, Wild-meat use, food security, livelihoods, and conservation, Conserv. Biol. 16 (2002) 580-583.

[3] W.M. Adams, J. Hutton, People, parks and poverty: political ecology and biodiversity conservation, Conserv. Soc. 5 (2007) 147.

[4] EUROPARC, IUCN, Guidelines for protected area management categories: interpretation and application of the protected area management categories in Europe, EUROPARC \& WCPA, Grafenau Germany, 2000.

[5] L. Coad, N.D. Burgess, B. Bomhard, C. Besançon, Progress towards the convention on biological diversity's 2012 and 2012 targets for protected area coverage, Jeju Island, Republic of Korea, 2009.

[6] B.S. Halpern, S. Walbridge, K.A. Selkoe, C.V. Kappel, F. Micheli, C. D’Agrosa, J.F. Bruno, K.S. Casey, C. Ebert, H.E. Fox, R. Fujita, D. Heinemann, H.S. Lenihan, E.M.P. Madin, M.T. Perry, E.R. Selig, M. Spalding, R. Steneck, R. Watson, A global map of human impact on marine ecosystems, Science. 319 (2008) 948-952. doi:10.1126/science.1149345.

[7] T. Potts, D. Burdon, E. Jackson, J. Atkins, J. Saunders, E. Hastings, O. Langmead, Do marine protected areas deliver flows of ecosystem services to support human welfare?, Mar. Policy. 44 (2014) 139-148. doi:10.1016/j.marpol.2013.08.011.

[8] S. Tapsuwan, J. Asafu-Adjaye, Estimating the Economic Benefit of SCUBA Diving in the Similan Islands, Thailand, Coast. Manag. 36 (2008) 431-442. doi:10.1080/08920750802412908. 
[9] P.F.M. Lopes, S. Pacheco, M. Clauzet, R.A.M. Silvano, A. Begossi, Fisheries, tourism, and marine protected areas: Conflicting or synergistic interactions?, Ecosyst. Serv. 16 (2015) 333-340. doi:10.1016/j.ecoser.2014.12.003.

[10] R.B. Francini-Filho, R.L. Moura, Evidence for spillover of reef fishes from a no-take marine reserve: An evaluation using the before-after control-impact (BACI) approach, Fish. Res. 93 (2008) 346-356. doi:10.1016/J.Fishres.2008.06.011.

[11] G.J. Edgar, R.D. Stuart-Smith, T.J. Willis, S. Kininmonth, S.C. Baker, S. Banks, N.S. Barrett, M.A. Becerro, A.T.F. Bernard, J. Berkhout, C.D. Buxton, S.J. Campbell, A.T. Cooper, M. Davey, S.C. Edgar, G. Försterra, D.E. Galván, A.J. Irigoyen, D.J. Kushner, R. Moura, P.E. Parnell, N.T. Shears, G. Soler, E.M.A. Strain, R.J. Thomson, Global conservation outcomes depend on marine protected areas with five key features, Nature. 506 (2014) 216-220. doi:10.1038/nature13022.

[12] A.M. Cisneros-Montemayor, M. Barnes-Mauthe, D. Al-Abdulrazzak, E. Navarro-Holm, U.R. Sumaila, Global economic value of shark ecotourism: implications for conservation, Oryx. 47 (2013) 381-388. doi:10.1017/S0030605312001718.

[13] J.E. Cinner, T.R. McClanahan, Socioeconomic factors that lead to overfishing in small-scale coral reef fisheries of Papua New Guinea, Environ. Conserv. 33 (2006) 73-80. doi:10.1017/S0376892906002748.

[14] D. Pauly, V. Christensen, J. Dalsgaard, R. Froese, F. Torres, Fishing down marine food webs, Science. 279 (1998) 860-863. doi:10.1126/science.279.5352.860.

[15] H. Grantham, S. Petersen, H. Possingham, Reducing bycatch in the South African pelagic longline fishery: the utility of different approaches to fisheries closures, Endanger. Species Res. 5 (2008) 291-299. doi:10.3354/esr00159.

[16] P.F.M. Lopes, E.M. Rosa, S. Salyvonchyk, V. Nora, A. Begossi, Suggestions for fixing top-down coastal fisheries management through participatory approaches, Mar. Policy. 40 (2013) 100110. doi:10.1016/j.marpol.2012.12.033.

[17] A. Agrawal, E. Ostrom, Collective Action, Property Rights, and Decentralization in Resource Use in India and Nepal, Polit. Soc. 29 (2001) 485-514. doi:10.1177/0032329201029004002.

[18] T.S. Brothers, Deforestation in the Dominican Republic: a village-level view, Environ. Conserv. 24 (1997) 213-223.

[19] E. Freedman, When indigenous rights and wilderness collide: prosecution of Native Americans for using motors in Minnesota's boundary waters Canoe Wilderness Area, Am. Indian Q. 26 (2002) 378-392. doi:10.1353/aiq.2003.0037.

[20] P.F.M. Lopes, L. Mendes, V. Fonseca, S. Villasante, Tourism as a driver of conflicts and changes in fisheries value chains in Marine Protected Areas, J. Environ. Manage. 200 (2017) 123-134. doi:10.1016/j.jenvman.2017.05.080.

[21] P. West, J. Igoe, D. Brockington, Parks and Peoples: The Social Impact of Protected Areas, Annu. Rev. Anthropol. 35 (2006) 251-277. doi:10.1146/annurev.anthro.35.081705.123308.

[22] A. Begossi, The sustainable development reserve of Mamirauá, Amazonas State, Brazil, Hirtshals, Denmark, 2002.

[23] P.F.M. Lopes, R.A.M. Silvano, A. Begossi, Extractive and Sustainable Development Reserves in Brazil: resilient alternatives to fisheries?, J. Environ. Plan. Manag. 54 (2011) 421-443.

[24] P. Christie, MPAs as biological sucesses and social failures in Southeast Asia, in: Aquat. Prot. Areas Fish. Manag. Tools Des. Use Eval. These Fully Prot. Areas, American Fisheries Society, Bethesda, 2004: pp. 275-284.

[25] M.A.M. Karper, P.F.M. Lopes, Punishment and compliance: Exploring scenarios to improve the legitimacy of small-scale fisheries management rules on the Brazilian coast, Mar. Policy. 44 (2014) 457-464. doi:10.1016/j.marpol.2013.10.012.

[26] IBGE Cidades, Estimativa da População 2011-2015, IBGE, Brasília, 2015. http://cidades.ibge.gov.br/xtras/perfil.php?codmun=260545 (accessed May 31, 2016). 
[27] N.M. Pires, R.C. Garla, A.R. Carvalho, The economic role of sharks in a major ecotourism archipelago in the western South Atlantic, Mar. Policy. 72 (2016) 31-39. doi:10.1016/j.marpol.2016.06.016.

[28] R.C. Garla, D.D. Chapman, B.M. Wetherbee, M. Shivji, Movement patterns of young Caribbean reef sharks, Carcharhinus perezi, at Fernando de Noronha Archipelago, Brazil: the potential of marine protected areas for conservation of a nursery ground, Mar. Biol. 149 (2006) 189-199. doi:10.1007/s00227-005-0201-4.

[29] R.C. Mitchell, R.T. Carson, Using surveys to value public goods: the Contingent Valuation method, Resources for the Future, 1989.

[30] M.E. Bond, E.A. Babcock, E.K. Pikitch, D.L. Abercrombie, N.F. Lamb, D.D. Chapman, Reef sharks exhibit site-fidelity and higher relative abundance in marine reserves on the mesoamerican Barrier Reef, PLOS ONE. 7 (2012) e32983. doi:10.1371/journal.pone.0032983.

[31] S.M. Thur, User fees as sustainable financing mechanisms for marine protected areas: An application to the Bonaire National Marine Park, Mar. Policy. 34 (2010) 63-69. doi:10.1016/j.marpol.2009.04.008.

[32] L. Venkatachalam, The contingent valuation method: a review, Environ. Impact Assess. Rev. 24 (2004) 89-124. doi:10.1016/S0195-9255(03)00138-0.

[33] J. Meyerhoff, U. Liebe, Protest beliefs in contingent valuation: Explaining their motivation, Ecol. Econ. 57 (2006) 583-594. doi:10.1016/j.ecolecon.2005.04.021.

[34] I. Marschner, glm2: Fitting Generalized Linear Models, 2014. https://CRAN.Rproject.org/package $=$ glm2.

[35] T. Agardy, P. Bridgewater, M.P. Crosby, J. Day, P.K. Dayton, R. Kenchington, D. Laffoley, P. McConney, P.A. Murray, J.E. Parks, L. Peau, Dangerous targets? Unresolved issues and ideological clashes around marine protected areas, Aquat. Conserv. Mar. Freshw. Ecosyst. 13 (2003) 353-367. doi:10.1002/aqc.583.

[36] I. Logar, J.C.J.M. van den Bergh, Respondent uncertainty in contingent valuation of preventing beach erosion: An analysis with a polychotomous choice question, J. Environ. Manage. 113 (2012) 184-193. doi:10.1016/j.jenvman.2012.08.012.

[37] L. Wood, Motives for poaching in Marine Protected Areas in the Seychelles, West. Indian Ocean J. Mar. Sci. 3 (2004) 199-208. doi:10.4314/wiojms.v3i2.28466.

[38] A. Begossi, P. May, P.F.M. Lopes, L.E.C. Oliveira, V. Vinha, R. Silvano, Compensation for environmental services from artisanal fisheries in SE Brazil: Policy and technical strategies, Ecol. Econ. 71 (2011) 25-32.

[39] T.W. Blaine, F.R. Lichtkoppler, K.R. Jones, R.H. Zondag, An assessment of household willingness to pay for curbside recycling: A comparison of payment card and referendum approaches, J. Environ. Manage. 76 (2005) 15-22. doi:10.1016/j.jenvman.2005.01.004.

[40] H. Nixon, J.-D.M. Saphores, Financing electronic waste recycling Californian households' willingness to pay advanced recycling fees, J. Environ. Manage. 84 (2007) 547-559. doi:10.1016/j.jenvman.2006.07.003.

[41] J.A. Puppim de Oliveira, Governmental responses to tourism development: three Brazilian case studies, Tour. Manag. 24 (2003) 97-110. doi:10.1016/S0261-5177(02)00046-8.

[42] M.A. de A. Corrêa, J.R. Kahn, C.E. de C. Freitas, Perverse incentives in fishery management: The case of the defeso in the Brazilian Amazon, Ecol. Econ. 106 (2014) 186-194. doi:10.1016/j.ecolecon.2014.07.023.

[43] E. Ostrom, A general framework for analyzing sustainability of social-ecological systems, Science. 325 (2009) 410-422.

[44] E. Ostrom, E. Schlager, The formation of property rights, in: S. Hanna, C. Folke, K.G. Maler (Eds.), Right Nat. Ecol. Econ. Cult. Polit. Princ. Inst. Environ., Island Press, Washington, D.C., 1996: pp. 130-132. 
[45] J.R. Irwin, P. Slovic, S. Lichtenstein, G.H. McClelland, Preference reversals and the measurement of environmental values, J. Risk Uncertain. 6 (1993) 5-18. doi:10.1007/BF01065347.

[46] G.K. Leonard, D. Mcfadden, Issues in the contingent valuation of environmental goods, in: Conting. Valuat. Crit. Assess., Emerald Group Publishing Limited, 1993: pp. 165-215. doi:10.1108/S0573-8555(1993)0000220007.

[47] S. Schwartzman, A. Moreira, D. Nepstad, Rethinking Tropical Forest Conservation: Perils in Parks, Conserv. Biol. 14 (2000) 1351-1357.

[48] D.A. Schkade, J.W. Payne, How People Respond to Contingent Valuation Questions: A Verbal Protocol Analysis of Willingness to Pay for an Environmental Regulation, J. Environ. Econ. Manag. 26 (1994) 88-109. doi:10.1006/jeem.1994.1006.

[49] H. Li, H.C. Jenkins-Smith, C.L. Silva, R.P. Berrens, K.G. Herron, Public support for reducing US reliance on fossil fuels: Investigating household willingness-to-pay for energy research and development, Ecol. Econ. 68 (2009) 731-742. doi:10.1016/j.ecolecon.2008.06.005.

[50] B.D. Solomon, N.H. Johnson, Valuing climate protection through willingness to pay for biomass ethanol, Ecol. Econ. 68 (2009) 2137-2144. doi:10.1016/j.ecolecon.2009.02.010.

[51] F. Reed Johnson, E. Lancsar, D. Marshall, V. Kilambi, A. Mühlbacher, D.A. Regier, B.W. Bresnahan, B. Kanninen, J.F.P. Bridges, Constructing Experimental Designs for Discrete-Choice Experiments: Report of the ISPOR Conjoint Analysis Experimental Design Good Research Practices Task Force, Value Health. 16 (2013) 3-13. doi:10.1016/j.jval.2012.08.2223.

[52] B. Fisher, T. Christopher, Poverty and biodiversity: Measuring the overlap of human poverty and the biodiversity hotspots, Ecol. Econ. 62 (2007) 93-101. doi:10.1016/j.ecolecon.2006.05.020.

[53] T. Agardy, G.N. di Sciara, P. Christie, Mind the gap: Addressing the shortcomings of marine protected areas through large scale marine spatial planning, Mar. Policy. 35 (2011) 226-232. doi:10.1016/j.marpol.2010.10.006. 